\title{
PENGARUH FAKTOR FUNDAMENTAL TERHADAP RETURN SAHAM PADA PERUSAHAAN SUBSEKOR MAKANAN DAN MINUMAN YANG TERDAFTAR DI BEI PERIODE 2013-2018
}

\author{
Risal Rinofah ${ }^{1}$; Elah Ria Cahyani ${ }^{2}$ \\ eria93320@gamil.com ${ }^{1}$; risal.rinofah@ustjogja.ac.id ${ }^{2}$
}

Fakultas Ekonomi, Universitas Sarjanawiyata Tamansiswa

\section{ABSTRAK}

This study aims to determine the effect of Current Ratio, Return On equity, Debt to Equity Ratio, dan Price Book Value on Stock Return. The population of this research is the food and beverage companies for the 2013-2018. Samples were taken using purposive sumping techniquie. The sample consisted of 11 companies from 16 food and beverage companies liested on the Indonesia Stock Exchange in 2013-2018, so the research data analyzed amounted to 60. Based on hypothesis testing using the t test, it is concluded that Current Ratio has a negative and significant effect on Stock Return, Return On Equity has a positive and significant effect on Stock Return, Debt to Equity Ratio has a negative and significant effect on Stock Return, Price Book Value has a significant negative effect.

Keyword:Stock Return, Current Ratio, Return On Equity, Debt to Equity Ratio, Price Book Value.

\section{PENDAHULUAN}

Perusahaan makanan dan minuman semakin lama semakin berkembang pesat, kondisi ini mendorong pesaing antara industri satu dengan yang lainnya. Perusahaan tentunya membutuhkan berbagai macam faktor-faktor produksi guna menunjang kegiatan operasionalnya, salah satunya modal atau pendanaan. Bursa Efek Indonesia atau Pasar modal memiliki peran penting bagi perekonomian suatu negara karena memiliki fungsi, sebagai sarana bagi perusahaan untuk mendapatkan dana dari masyarakat pemdal (investor).

Kegiatan investasi dipasar modal merupakan suatu kegiatan menetapkan dana pada satu atau lebih asset selama periode tertentu dengan harapan dapat memperoleh pendapatan atau peningkatan atas nilai investasi awal (modal) yang bertujuan untuk memaksimalkan hasil (return) yang diharapkan dalam batas resiko yang dapat diterima investor. (Jogiyanto,2003). Dalam pengambilan keputusan investasi pada suatu perusahaan, investor umumnya melakukan analisis fundamental yang didapat dari analisis laporan keuangan perusahaan emiten. Analisis fundamental menyatakan bahwa tingkat keuntungan perusahaan

E-ISSN: 2777-1156

2021. Vol 5. No 2 
Fakultas Ekonomi, Universitas Cokroaminoto Yogyakarta akan mempengaruhi harga saham, semakin tinggi tingkat keuntungan, semakin tinggi harga saham. Natarsyah (2000) menyatakan bahwa dengan asumsi para investor adalah rasional maka aspek fundamental menjadi dasar penelitian yang utama bagi para fundamentalis. Dalam analisis fundamental murni, investor dapat melakukan analisis berdasarkan kinerja perusahaan. Analisis ini terutama menyangkut faktor-faktor yang memberi informasi tentang kinerja perusahaan, seperti kemampuan manajemen dalam mengelola kegiatan operasional perusahaan, prospek bisnis perusahaan dimasa mendatang dan sebagainya.

Faktor fundamental dapat dilihat dari beberapa rasio keuangan meliputi rasio likuditas yaitu Current Ratio, rasio profabilitas yaitu Return On Equity, rasio solvabilitas yaitu Debt to Equity Ratio dan rasio penelitian kinerja yaitu Price Book Value. Beberapa penelitian telah dilakukan untuk menganalisis faktor-faktor yang dapat mempengaruhi return saham. Penelitian tersebut diantaranya yang dilakukan oleh Nur Amalia (2014), menujukan bahwa DER berpengaruh negatif signifikan terhadap return saham. Menurut penelitian Hartati (2010) menujukan bahwa DER berpengaruh signifikan terhadap return saham. Menurut Ryan Novitasari (2013) menujukan bahwa DER berpengaruh negatif signifikan terhadap return saham.

Penelitian ini memiliki tujuan untuk mengetahui signifikansi pengaruh faktor fundamental terhadap return saham. Dari uraian diatas, maka penulis terdorong untuk membuat suatu karya ilmiah berbentuk skripsi dengan judul "Pengaruh Faktor Fundamental terhadap Return Saham pada Perusahaan Subsektor Makanan dan Minuman yang terdaftar di Bursa Efek Indonesia."

\section{TINJAUAN TEORI}

\section{Pasar Modal}

Pasar modal adalah salah satu alternatif investasi bagi masyarakat. Melalui pasar modal, investor dapat melakukan investasi dibeberapa perusahaan melalui pembelian suratsurat berharga yang ditarwarkan atau yang diperdaangkan di pasar modal. Sementara itu, perusahaan atau sering disebut sebagai emiten dapat memperoleh dana yang dibutuhkan dengan menawarkan suat-surat berharga tersebut. Adanya pasar modal memungkinkan para investor untuk memilki perusahaan yang sehat dan berprospek sehat. Penyebaran kepemilikan yang luas akan mendorong perusahaan melakukan trnasparasi laporan keuangan. Hal ini akan mendorong perusahaan menuju terciptanya good corporate goverence. (Hermunungsih,2012)

\section{Investasi}

Investor yang melakukan invetasi pada saham akan berhadapan dengan risiko penurunan harga saham dan kemungkinan saham perusahaan dikeluarkan dari bursa (delist) karena alasan tertentu bahkan lebih jauh lagi investor juga menghadapi kemungkinan perusahaan dipailitkan atau bangkrut. Sementara itu investor yang melakukan investasi didalam bentuk obligasi akan mengalami risisko investasi berupa tidak dibayarkannya bunga (coupun) oleh perusahaan, yang sering disebut dengan default.

\section{E-ISSN: $2777-1156$}

2021. Vol 5. No 2 
Fakultas Ekonomi, Universitas Cokroaminoto Yogyakarta

\section{Informasi Fundamental}

Pada saat melakukan investasi dalam bentuk saham diperlukan informasi untuk memperdiksi nilai saham, yaitu analisis fundamental dan analisis teknikal. Thiagarjant dan Lev (1993) yang menyatakan bahwa analisis fundamental bertujuan menentukan nilai dari surat-surat berharga perusahaan dengan suatu pengujian seksama pada kunci value-driver, seperti laba, resiko, pertumbuhan, dan competitive position.

\section{KERANGKA PIKIR}

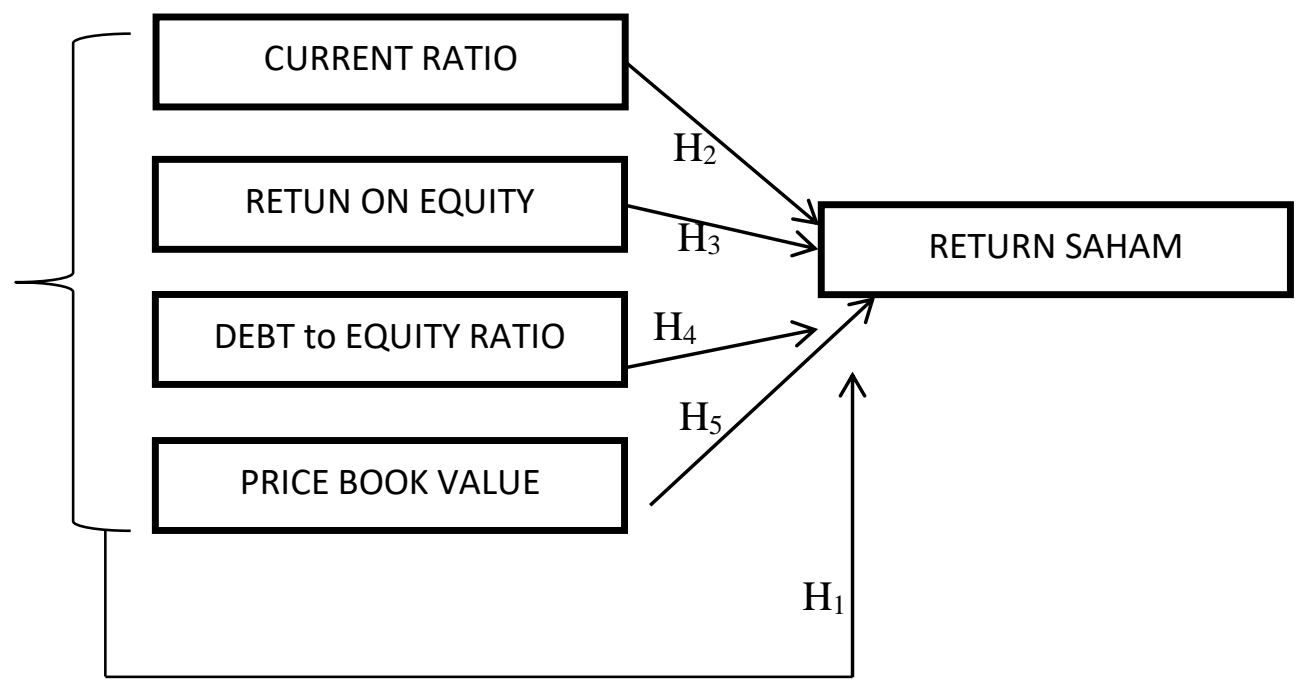

Gambar 1. Kerangka Pikir Penelitian

Berdasarkan pengembangan hioptesis dapat diajukan suatu hioptesis sebagai berikut:

$\mathrm{H}_{1}$ : Variabel Current Ratio, Return On Equity, Debt to Equty Ratio, dan Price Book Value terhadap return saham

$\mathrm{H}_{2}$ : Current Ratio berpengaruh postif terhadap Return saham

$\mathrm{H}_{3}$ : Return On Equity berpengaruh positif terhadap Return Saham

$\mathrm{H}_{4}$ : Debt to Equty Ratio berpengaruh positif terhadap Return Saham

$\mathrm{H}_{5}$ : Price Book Value berpengaruh positif terhadap Return Saham 


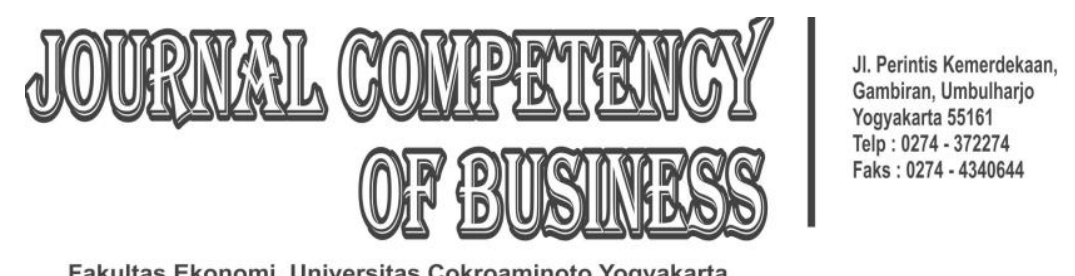

Fakultas Ekonomi, Universitas Cokroaminoto Yogyakarta METODE PENELITIAN

\section{Populasi, Sampel dan Teknik Pengambilan Sampel}

Populasi dalam penelitian ini sebanyak 50 dan sampel yang digunakan dalam perusahaan ini sebanyak 10 peusahaan subsektor makanan dan minuman yang terdaftar di Bursa Efek Indonesia yang telah Go Public. Metode yang digunakan dalam penelitian ini metode purposive sampling. Hal ini dilakukan agar data yang diperoleh sesuai dengan tujuan penelitian relatif memungkinkan untuk dibandingkan dengan hasil-hasil penelitian sebelumnya. Bersadarkan metode tersebut maka sampel dari penelitian dipilih dari perusahaan manufaktur yang terdaftar di Bursa Efek Indonesia kriteria-kriteria sebagai berikut:

1. Perusahaan subsektor makanan dan minuman yang terdafatr di Bursa Efek Indonesia yang melaporkan deviden selama tahun pengamatan tahun 2013-2018

2. Menerbitkan laporan keuangan paling tidak pada periode 31 Desember 2013 sampai 31 Desember 2018

\section{Definisi Operasional}

\section{Return Saham}

Return saham adalah keuntungan yang dinikmati oleh pemodal atas investasi yang dilakukannya. Konsep return saham dalam penelitian ini adalah perbandingan antara selisih harga saham saat ini dengan harga saham periode sebelumnya ditambah deviden dibagi dengan harga saham periode sebelumnya. Adapun nilai clossing price dalam penelitian ini diambil clossing price tahunan yang tercantum dalam Bursa Efek Indonesia (Samsul,2006). Rumus untuk menghitung return saham sebagai berikut:

$$
\mathrm{Rt}=\frac{P_{t}-P_{t-1}}{P_{t}-1}
$$

Keterangan:

$\mathrm{R}_{\mathrm{t}} \quad$ : Retun Saham

$\mathrm{P}_{\mathrm{t}} \quad$ : Harga saham pada akhir periode

$\mathrm{P}_{\mathrm{t}-1} \quad$ : Harga Saham periode awal 


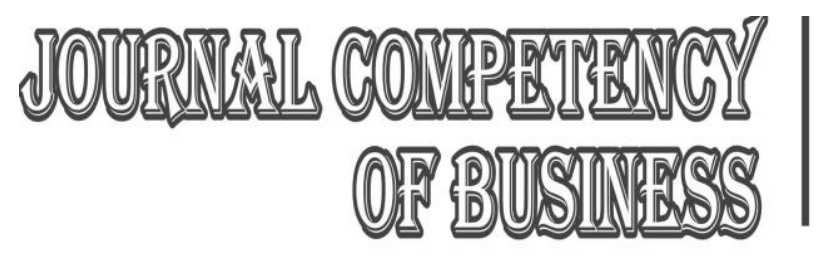

Fakultas Ekonomi, Universitas Cokroaminoto Yogyakarta

\section{Current Ratio}

Current ratio merupakan rasio likuditas yang biasa digunakan untuk mengukur kemampuan perusahaan dalam memenuhi kewajiban jangka pendeknya dengan aktiva yang dimilikinya. Current ratio dinilai dapat mempengaruhi harga saham karena nilai Current ratio yang tinggi menggambarkan perusahaan likuid sehingga dianggap mampu dalam memenuhi kewajiban jangka pendeknya dan dapat menarik minat para investor untuk melakukan investasi (Kasmir,2012)

$$
\mathrm{CR}=\frac{\text { Current Asset }}{\text { Current Liabilites }} \times 100 \%
$$

\section{Return On Equity}

Return on Equity adalah kemampuan perusahaan untuk menghasilkan laba bersih setelah pajak dengan menggunakan modal sendiri yang dimiliki perusahaan. Rasio ini penting bagi pemegang saham, untuk mengetahui efektifitas dan efisiensi pengelolaan modal sendiri yang dilakukan oleh pihak manajemen perusahaan. Semakin tinggi rasio ini semakin efisien penggunaan modal sendiri yang dilakukan pihak manajemen perusahaan. (Sudana,2015)

$$
\mathrm{ROE}=\frac{\text { Net Income After Tax }}{\text { Total Shareholder }{ }^{\prime} \text { sEquity }} \times 100 \%
$$

\section{Debt to Equity Ratio}

Debt to Equity Ratio merupakan rasio yang digunakan untuk memenuhi modal sendiri untuk dijadikan sebagai jaminan utang. Kebijakan hutang dalam hal ini diproksikan dengan DER yaitu kebijakan yang menetukan seberapa besar kebutuhan dana perusahaan dibiayai oleh hutang. ( Kasmir, 2008)

$$
\text { Debt to Equity Ratio }=\frac{\text { Total Hutang }}{\text { Total Ekuitas }} \times 100 \%
$$

\section{Price Book Value}

Price Book Value adalah mengukur penilaian pasar keuangan terhadap manajemen dan organisasi perusahaan sebagai going concern. Nilai buku saham mencerminkan nilai historis dari aktivitas perusahaan. Perusahaan yang dikelola dengan baik dan beroperasi secara efiseien dapat memiliki nilai pasar yang lebih tinggi daripada nilai buku assetnya. ( Sudana, 2011) 


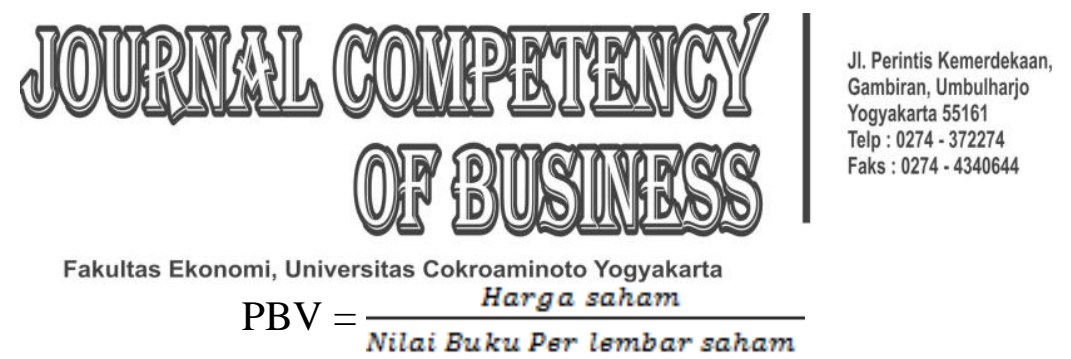

\section{HASIL PENELITIAN}

\section{Uji Asumsi Klasik}

\section{Uji Normalitas}

Uji Normalitas bertujuan untuk mengetahui apakah dalam model regresi variabel terikat dan variabel bebas memiliki distribusi data normal atau mendekati normal. Hasil Kolmogorov-Smirnov test menunjukan hasil Asymp. Sig (2-tailed) menunjukan angka 0,065 yang berarti berada di atas 0,05 dengan demikian dapat disimpulkan bahwa data residual terdidtibusi normal.

\section{Uji Multikolinearitas}

Multikolinearitas adalah terdapatnya lebih dari dari satu hubungan linear pasti (sempurna). Dimana suatu keadaan yang satu atau lebih variabel bebasnya terdapat korelasi dengan variabel bebas lainnya. Adanya multikolinearitas dapat dilihat dari tolerance value atau nilai variance Inflation Factor (VIF). Ketentuan dari VIF untuk uji multikolinearitas adalah jika VIF kurang dari 10 dan tolerance lebih dari 0,10 maka dapat dikatakan tidak ada masalah multikolinearitas. Hasil uji multikolinearitas ini menujukan bahwa tidak terdapat multokolinearitas model. Nilai tolerance CR sebesar 0,548, ROE sebesar 0,732, DER sebesar 0,514, PVB sebesar 0,648. Nilai VIF CR sebesar 1,826, ROE sebesar 1,366, DER sebesar 1,946, dan PVB sebesar 1,543. Jadi dapat disimpulkan bahwa tidak ada multokolinearitas antar variabel independen dalam model regresi.

\section{Uji Autokorelasi}

Uji Autokorelasi bertujuan menguji apakah dalam model regresi linear ada korelasi antara kesalahan penggangu pada periode $\mathrm{t}$ dengan kesalahan penggangu pada periode t-1 (sebelumnya). Jika terjadi korelasi, maka dinamakan ada froblem autokorelasi. Autokorelasi dapat diketahui menggunakan besaran Durbin-Watson (D-W) pada output pengujian. Nilai (D-W) test tersebut dibandingkan dengan nilai pada tabel Durbin-Watson dengan menggunakan tingkat keyakinan sebesar 95 persen dengan ketentuan bila dU < DW < 4 - dU, maka tidak terjadi autokorelasi. Nilai DW sebesar 2,002. Dengan jumlah data sebesar 60 dan jumlah varaibel bebas 4 serta $\alpha=5 \%$ diperoleh angka dU $=1,444$ dan $\mathrm{dL}=1,727$. Karena DW sebesar 2,002, terletak diantara dU dan dL (4 - 1,444 = 2,556), maka dapat disimpulkan dalam model regresi ini tidak terjadi autokorelasi.

E-ISSN: 2777-1156

2021. Vol 5. No 2 
Fakultas Ekonomi, Universitas Cokroaminoto Yogyakarta

\section{Uji Heterkedasitas}

Uji Heterokedasitas bertujuan untuk melihat apakah dalam model regresi terjadi ketidaksamaan variabel residu satu pengamatan ke pengamatan yang lain. Salah satu cara mendeteksi ada atau tidaknya heterodekasitas adalah dengan melihat grafik plot antara nilai prediski variabel terkait dengan residualnya. Jika ada plot tertentu, seperti titik-titik menyebar diatas dan dibawah angka 0 pada sumbu Y, maka tidak terjadi heterokedasitas. Hal ini dapat disimpulkan bahwa tidak terjadi heterokedasitas pada model regresi.

\section{Uji Hipotesis}

\section{Hasil Uji Analisis Linear Berganda Uji F ( Fit Model)}

Uji kelayakan model (uji F ) bertujuan untuk menguji apakah semua variabel bebas berpengaruh terhadap variabel terikat dan untuk mengetahui model regresi yang digunakan dalam penelitian ini layak uji atau tidak. Jika nilai signifiaknsi $F<0,05$ maka koefisiens regresi signifikan. Jika nilai signifikansi $F>0,05$ maka koefisien regresi tidak signifikan.

Hasil pengujian diketahui bahwa nilai signifikansi 0,79>0,05 maka sesuai dengan dasar pengambilan akan ditolak jika nilai signifikansi lebih besar dari 0,05.

\section{Uji Koefisien Determinasi}

Uji koefisien determinasi $\left(\mathrm{R}^{2}\right)$ pada intinya mengukur seberapa jauh kemampuan model dalam menerangkan variasi variabel dependen. Nilai koefisien deteriminasi adalah antara nilai nol dan satu. Nilai $\mathrm{R}^{2}$ kecil berarti kemampuan variabelvariabel independen memberikan hampir semua informasi untuk memprediski variasi variabel dependen.

Hasil pengujian ini memperoleh nilai Adjusted $R$ Square adalah 0,73 hal ini menujukan bahwa variabel independen berpengaruh sebesar 0,927 terhadap varaibel dependen, sedangkan 7,3 dipengaruhi oleh variabel tidak teliti. Karena R Square dibawah 5\% atau cenderung mendekati 0 , maka dapat disimpulkan kemampuan varaibel-varaibel independen dalam menjelaskan variasi variabel amat terbatas.

\section{Uji statistik t}

Uji t digunakan untuk menguji signifiakan pengaruh satu variabel bebas secara individu terhadap varaibel terikat. Jika nilai signifikansi $t<0,05$ maka terdapat pengaruh antara satu variabel independen terhadap varaibel dependen. Jika nilai $t>0,05$, maka tidak terdapat pengaruh antara satu variabel independen terhadap variabel dependen. Hasil uji statistik t dapat diihat sebagai berikut : 
Fakultas Ekonomi, Universitas Cokroaminoto Yogyakarta

Tabel 1. Pengujian Hipotesis

\begin{tabular}{|c|c|c|c|c|c|c|}
\hline \multicolumn{7}{|c|}{ Coefficients $^{a}$} \\
\hline \multirow{3}{*}{\multicolumn{2}{|c|}{ Model }} & \multirow{2}{*}{\multicolumn{2}{|c|}{ Unstandardized Coefficients }} & \multirow{3}{*}{$\begin{array}{c}\text { Standardized } \\
\text { Coefficients } \\
\text { Beta } \\
\end{array}$} & \multirow[b]{3}{*}{$t$} & \multirow[b]{3}{*}{ Sig. } \\
\hline & & & & & & \\
\hline & & $\mathrm{B}$ & Std. Error & & & \\
\hline \multirow[t]{5}{*}{1} & (Constant) & .593 & .224 & & 2.650 & .010 \\
\hline & $\mathrm{CR}$ & -.053 & .046 & -.196 & -1.157 & .252 \\
\hline & ROE & .340 & .190 & .262 & 1.789 & .079 \\
\hline & DER & -.291 & .140 & -.363 & -2.078 & .042 \\
\hline & PBV & -.007 & .003 & -.348 & -2.235 & .030 \\
\hline
\end{tabular}

a. Dependent Variable: RETURN

Berdasarkan tabel diatas didapat hasil uji regresi linear menjelaskan bahwa :

1. CR berpengaruh positif terhadap Return Saham

Current Ratio meemiliki koefisien beta,- 053 dan bertanda negatif. Nilai signifikansinya sebesar 0.252 lebih besar dibandingkan dengan 0.05 , artinya ada pengaruh negatif yang tidak signifikan variabel Current Ratio terhadap Return Saham.

Berdasarkan uraian dapat dikatakan bahwa hipotesis 1 yang berbunyi Current Ratio berpengaruh positif terhadap terhadap Return saham tidak terbukti.

2. ROE berpengaruh positif terhadap Return Saham

Return On Equity (ROE) memiliki koefisien beta .340 dan bertanda positif. Nilai signifikansinya sebesar 0.079 lebih besar dibandingkan dengan 0.05, artinya ada pengaruh positif variabel Return On Equity terhadap Return Saham.

Berdasarkan uraian dapat dikatakan bahwa hipotesis 2 yang berbunyi Return On Equity berpengaruh positif tidak signifikan terhadap Return Saham terbukti.

3. DER berpengaruh positif terhada Return Saham

Debt to Equity Ratio memiliki koefisien beta -.291 dan bertanda negatif. Nilai signifikansinya sebesar 0.042 lebih kecil diabndingkan dengan 0.05 , artinya ada pengaruh negatif variabel Debt to Equity Ratio terhadap return Saham.

Berdasarkan uraian dapat dikatakan bahwa hipotesis 3 yang berbunyi Debt to Equity Ratio berpengaruh positif terhadap Return saham, tidak terbukti.

4. PBV berpengaruh positif terhadap Return saham

Price Book Value memiliki koefisien beta -.007 dan bertanda positif. Nilai signifikansinya sebesar 0.030 yang lebih kecil dibandingkan dengan 0.05 , artinya ada pengaruh positif variabel Price Book Value terhadap Return Saham.

Berdasarkan uraian dapar dikatakan bahwa hipotesis 4 yang berbunyi Price Book Value berpengaruh positif terhadap Return Saham, terbukti. 


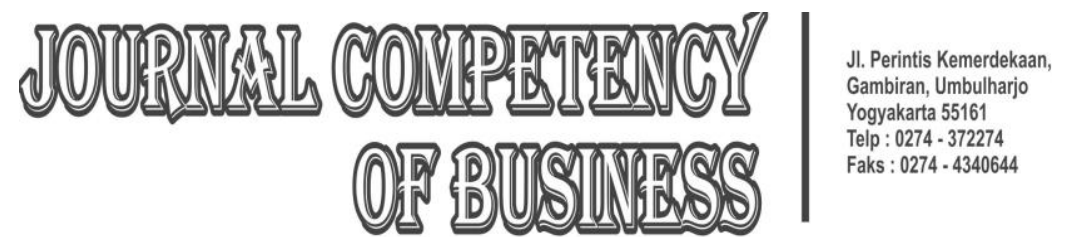

Fakultas Ekonomi, Universitas Cokroaminoto Yogyakarta

\section{Pembahasan Penelitian}

\section{Pembahasan Penelitian secara Simultan}

Berdasarkan nilai signifikansinya lebih besar dari 0.05 yaitu sebesar 0.085 dengan $\mathrm{F}$ hitung 2.164. dengan demikian dapat diambil kesimpulan bahwa Current Ratio, Return On Equity, Debt to Equity Ratio, Price Book Value secara simultan tidak berpengaruh terhadap Return saham.

\section{Hasil Penelitian secara Parsial}

\section{a. Pengaruh Current Ratio terhadap Return Saham}

Berdasarkan hasil uji $\mathrm{t}$ yang dilakukan dalam penelitian ini menujukan bahwa variabel Current Ratio mempunyai tingkat signifikan $0.252>0.05$ sedangkan nilai B ,053. Berdasarkan kedua nilai tersebut maka dapat disimpulkan bahwa Current Ratio tidak berpengaruh signifikan terhadap return saham. Artinya dalam pengambilan keputusan investasi, Current Ratio tidak begitu diperlukan oleh investor.

Nilai B -.053 menujukan bahwa bila Current Ratio naik reurn saham turun sebaliknya jika CR turun Return naik. Hal ini disebabkan karena nilai Current Ratio yang tinggi tidak mempengaruhi minat investor dalam menanamkan modalnya, karena dengan tingginya nilai Current Ratio berarti pengelolaan aktiva lancar kurang berjalan dengan baik, sehingga banyak aktiva lancar yang menanggur dan tidak dioptimalkan oleh perusahaan sehingga mengakibatkan menurunnya minat investor untuk menanamkan modalnya.

Hasil penelitian ini didukung oleh penelitian Nur Amalia (2014), menyatakan bahwa CR berpengaruh negatif tidak signifikan terhadap Return saham.

\section{b. Pengaruh Return On Equity terhadap Return Saham}

Berdasarkan hasil uji t yang dilakukan ini menunjukan bahwa variabel Return On Equity mempunyai tingkat signifikan $0.079>0.05$ sedangkan nilai B .340 . berdasarkan kedua nilai tersebut maka dapat disimpulkan bahwa Retrun On Equity berpengaruh positif tidak signifikan terhadap Return Saham. artinya bahwa dalam pengambilan keputusan investasi, Return On Equity tidak begitu diperlihatkan oleh investor.

Nilai B ,340 menunjukan bila ROE naik return saham naik, bila ROE turun return saham turun.

Tidak signifikannya ROE terhadap Return saham disebabakan bahwa perusahaan tidak bisa melakukan manajemen laba, akibatnya ROE yang dimiliki tidak mampu menggambarkan tingkat profitabilitas perusahaan seseungguhnya sehingga belum mencerminkan besarnya pengembalian modal dari perusahan.

Hasil penelitian ini sejalan dengan penelitian Aminah (2014)

\section{c. Pengaruh Debt to Equity Ratio terhadap Return saham}

Berdasarkan hasil uji t yang dilakukan ini menujukan bahwa Debt to Equity Ratio mempunyai tingkat signifikan $0.042<0.05$ sedangkan nilai $\mathrm{B}-, 291$. Berdasarkan kedua nilai tersebut maka dapat disimpulkan bahwa, ini menujukan bahwa Debt to Equity Ratio berpengaruh signifikan terhadap Return saham. artinya variavel DER menjadi bahan petimbangan investor dalam menentukan keputusan investasi.

E-ISSN: $2777-1156$

2021. Vol 5. No 2 


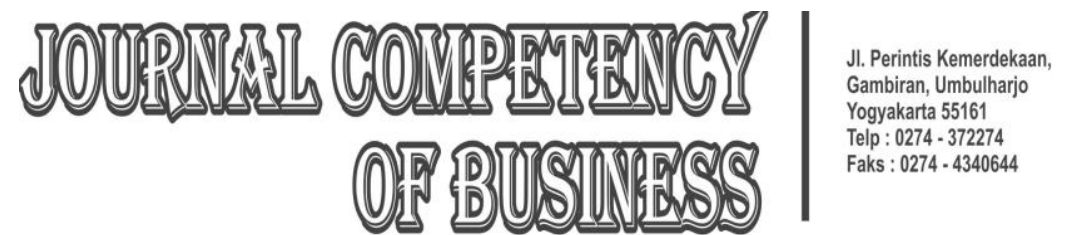

Fakultas Ekonomi, Universitas Cokroaminoto Yogyakarta

Nilai B -,291 menujukan bahwa jika DER naik maka rerurn saham naik dan jika DER turun return saham turun. Berarti pada industri ini investor lebih suka DER yang tinggi, karena tingginya DER menujukan bahwa, dari laba yang diperoleh perusahaan meingkatkan pembahian deviden untuk investor/ pemegang saham, sehingga untuk meningkatkan kebutuhan modalnya, perusahaan menggunakan hutang.

Hal ini sejalan dengan penelitian yang dilakukan oleh Ika Afifta Nelia (2014), yang menyatakan bahwa DER berpengaruh negatif signifikan terhadap Return saham

\section{d. Pengaruh Price Book Value terhadap return saham}

Berdsarakan hasil uji t yang dilakukan ini menujukan bahwa variabel Price Book Value mempunyai tingkat signifikan $0.030<0.05$ sedangkan nilai B -.007. berdasarkan dari kedua nilai tersebut dapat disimpulkan bahwa Price Book Value berpengaruh negatif signifikan terhadap Return saham.

Hal ini disebabkan karena investor tidak lagi beranggapan bahwa PBV dapat digunakan sebagai patokan untuk membeli saham namun lebih mempertimbangkan hal-hal lain.

Teori ini sejalan dengan penelitian yang dilakukan oleh Ika Afifta Nelia (2014), menyakatakn bahwa PBV berpengaruh negatif signifikan terhadap return saham.

\section{SIMPULAN}

1. Variabel Current Ratio berpengaruh negative tidak signifikan terhadap Return saham.

2. Variabel Return On Equity berpengaruh positif tidak signifikan terhadap Return saham.

3. Varibel Debt to Equity Ratio berpengaruh negative signifikan terhadap Return saham.

4. Variabel Price Book Value berpengaruh negative signifikan terhadap Return saham.

\section{SARAN}

Adapun saran-saran yang dapat diberikan melalui hasil penelitian ini adalah:

1. Bagi Perusahaan

Mencari hasil penelitian sejenis dengan variabel lain, untuk dapat mengetahui dan memahami faktor apa yang menjadi pertimbangan investor untuk membeli saham.

2. Bagi Investor

Disarankan untuk memperhatikan variabel lainnya dalam informasi keuangan yang diberikan perusahaan agar dapat membuat keputusan yang tepat untuk memberikan investasinya kepada perusahaan.

3. Bagi Akademis

Penelitian ini diharapkan dapat digunakan sebagai penamba wawasan dan pengetahuan, serta dapat menjadi referensi atau literatur penelitian lebih lanjut lagi dengan judul dan tema sejenis. 
Fakultas Ekonomi, Universitas Cokroaminoto Yogyakarta

DAFTAR PUSTAKA

Aftita Nelia,Ika,. 2014. Pengaruh Faktor Fundamental dan Risiko Sistematis terhadap Return Saham Manufaktur : STIESIA

Anismawati,Novita. 2019. Pengaruh Current Ratio (CR), Return On Asset (ROA), dan Debt to Equity Ratio (DER) terhadap Harga Saham pada perusahaan Makanan dan Minuman yang terdaftar di Bursa Efek Indonesia periode 2013-2017 : Fakultas Ekonomi Universitas Sarjanawiyata Tamansiswa.

Choirurodin. 2018. Pengaruh Current Ratio, Return On Equity, Debt to Equity Ratio terhadap Return Saham ( Pada Perusahaan Food and Bererages yang Terdaftar di BEI periode 2013-2016) : Fakultas Ekonomi Universitas Negeri Yogyakarta.

Darmaji,Tjiptopo dan Fakhrudin, Hendy M. 2001. Pasar Modal di Indonesia Pendekatan Tanya Jawab Edisi Pertama. Jakarta: Salemba Empat.

Drs. Martono S.U dan Drs. D. Agus Hartono,Msi. (2005). Manajemen Keuangan edisi pertama catatan kelima : Ekonesic Fakultas Ekonomi UII

Hermuningsih,Sri. 2012. Pengantar Pasar Modal Indonesia. Yogyakarta : UPP STIM YKPN

Hidayat, Muhammad Rayon. (2006), Faktor Fundamental terhadap Return Saham (study kasus pada perusahaan Farmasi yang terdaftar di BEI tahun 2005-2014) : Fakultas Ekonomi Universitas Sarjanwiyata Tamansiswa.

Maulita, Prayudita. 2019. Pengaruh Debt to Equity Ratio (DER), Return On Asset (ROA), dan Net Profit Margin (NPM) terhadap Return Saham industri realestate and Property yang Terdaftar di Bursa Efek IndonesiamPeriode 2013-2017 : Fakultas Ekonomi Universitas Sarjanawiyata Tamansiswa.

Qadari, Nur Laili. (2017), Pengaruh Growth, DFL, dan ROE terhadap Return Saham pada Perusahaan Pertambangan Batu Bara di BEI : STIESIA

Samsul, Mohamad. 2015, Pasar Modal dan Manajemen Portofolio. Jakarta : ERLANGGA

Santoso, Singgih. 2000. Buku Latihan SPSS Statistik Parametrik. Jakarta : PT. Elex Media Komputindo-Jakarta

Sartono, Agus R. 1990. Manajemen Keuangan Teori dan Aplikasi Edisi Pertama. Yogyakarta: BPFE-YOGYARTA

Sudana, i Made. (2011), Manajemen Keuangan Perusahaan : ERLANGGA. 